\title{
AKTIVITAS FISIK RUTIN SEBAGAI MODULATOR SENSITIVITAS INSULIN PADA OBESITAS
}

\author{
Dian Syafitri', Khairun Nisa Berawi ${ }^{2}$, Ahmad Arkan Ichsan ${ }^{3}$ \\ ${ }^{1}$ Prodi Pendidikan Dokter, Fakultas Kedokteran, Universitas Lampung \\ ${ }^{2}$ Bagian Fisiologi, Fakultas Kedokteran, Universitas Lampung \\ Email: diansyafitri384@gmail.com ${ }^{1}$; nisaberawi0226@gmail.com;
}

a.khan.ich@gmail.com

\begin{abstract}
Obesity is a state of abnormal or excessive fat accumulation in the adipose tissue of the body that could potentially cause the health problems. The prevalence of obesity increases every year in Indonesia. Based on the Basic Health Research 2018, Indonesian obesity incidences ranked 18, 8\% in 2007, increased to 26, 6\% in 2013 and topping 31, 0\% in 2018. The increase of obesity prevalence is directly proportional to comorbid conditions. Insulin insensitivity is seen in obese patients, and may lead to insulin resistance. This correlates with a disrupted glucose absorption rate, which is induced by insulin. Glucose molecules could not enter the cell and could not be utilized by the cells, as a result there is an n increase in blood glucose levels. Conditions with abnormally high glucose levels is called hyperglycemia. Hyperglycemia can lead into a variety chronic diseases, like diabetes mellitus. One of the straightforward, cost-effective and efficacious therapy strategies that can be executed to overcome obesity and increase the insulin sensitivity is through increased physical activity. Categories of physical activity are divided between sedentary, light, moderate, vigorous, and high, where each category has varying energy demands. Physical activity that is carried out consistently and routinely may further reduce body weight, as well as maintain proportional body weight in the long run and further increase insulin sensitivity, and reduce the risk chronic disease like diabetes mellitus.
\end{abstract}

Keywords : Insulin Resistance, Insulin Sensitivity, Obesity, Physical Activity

\section{PENDAHULUAN}

Obesitas saat ini merupakan salah satu masalah kesehatan masyarakat utama karena merupakan kontributor utama penyakit kronis (Goossens, 2017). Obesitas merupakan penyakit yang kompleks, multifaktorial dan sebagain besar dapat dicegah (Hruby \& $\mathrm{Hu}$, 2015). Obesitas terjadi didorong oleh pertumbuhan ekonomi, industrialisasi, urbanisasi, gaya hidup dan transisi nutrisi ke makanan olahan serta diet tinggi kalori (Popkin, Adair \& Ng, 2013). Hal ini menjadi tantangan yang besar dalam pencegahan penyakit kronis (Hruby \& Hu, 2015).

Berdasarkan data dari Riskesdas tahun 2007, 2013, dan 2018 angka obesitas cenderung meningkat. Prevalensi kejadian obesitas sentral di Indonesia sebanyak 18,8\% pada tahun 2007, 26,6\% pada tahun 2013 dan $31,0 \%$ pada tahun 2018. Prevalensi penduduk laki-laki dewasa obesitas pada tahun 2007 sebesar 13,9\%, 2010 7,8\% dan 2013 19,7\%. Prevalensi perempuan dewasa obesitas pada tahun 2007 sebesar 13,9\%, 2010 sebesar 
15,5\% dan 2013 sebesar 32,9\%. Hal ini menunjukkan angka kejadian obesitas yang terus mengalami peningkatan (Riskesdas, 2018).

Prevalensi obesitas yang terus meningkat menjadi perhatian dunia. Onset obesitas dini merupakan faktor resiko untuk terjadinya penyakit penyerta (komorbiditas) dimasa dewasa (Borgeraas, et al., 2018. Penyakit yang dapat disebabkan oleh obesitas antara lain penyakit kardiovaskular, hipertensi, obstructive sleep apnea (OSA), asma, depresi dan diabetes melitus tipe 2 (Llewellyn, Simmonds, Owen, Woolacott, 2016), (Bazzano, et al., 2016). Sebuah study cross sectional menunjukkan bahwa obesitas dapat meningkatkan faktor resiko terjadinya diabetes mellitus terutama pada wanita (Borgeraas, 2018). Hal ini karena menurunnya sensitivitas insulin dan berkembangnya resistensi insulin pada obesitas (Segula, 2014).

Kombinasi antara aktivitas fisik dan pembatasan diet kalori diperlukan untuk mengatasi obesitas (DiPietro \& Stachenfeld, 2017). Aktivitas fisik merupakan setiap gerakan terencana, terstruktur dan berulang yang dihasilkan oleh otot rangka dan membutuhkan pengeluaran energi untuk mempertahankan atau meningkatkan komponen kebugaran fisik (Gonzales, Fuentes \& Markues, 2017). Aktivitas fisik yang dilakukan secara rutin mampu meningkatkan sensitivitas insulin dan memperlambat terjadinya resistensi insulin pada obesitas. Selain itu, aktivitas fisik juga mampu meningkatkan fungsi kardiovaskuler dan metabolisme sehingga dapat mencegah terjadinya dislipidemia dan penyakit kardiovaskuler seperti hipertensi (DiPietro \& Stachenfeld, 2017).

Rumusan masalah dalam studi literatur ini adalah apakah aktivitas fisik dapat menjadi modulator sensitivitas insulin dan mampu menghambat terjadinya resistensi insulin?. Tujuan studi literatur ini adalah untuk menjelaskan proses terjadinya resistensi insulin pada obesitas dan proses daripada aktivitas fisik dalam meningkatkan sensitivitas insulin pada obesitas.

\section{METODE PENELITIAN}

Jenis penelitian ini kualitatif menggunakan desain deskriptif. Data diperoleh dari tinjauan pustaka di PubMed dan NCBI. Pencarian literatur menggunakan kata kunci: insulin reistance, insulin sensitivity, obesity, physical aktivity. Literatur yang digunakan batas waktu maksimal 15 tahun sejak pertama kali publikasi.

\section{HASIL}

Obesitas merupakan suatu keadaan akumulasi lemak abnormal atau berlebihan pada jaringan adiposa tubuh yang dapat mengganggu kesehatan (Bhadoria, et al,. 2015). Hal ini terjadi karena intake kalori yang berlebihan (pemasukan kalori) dibandingkan dengan pengeluaran energi (WHO, 2018). Peningkatan asupan makanan 
padat energi yang tinggi lemak, tinggi lemak, tinggi glukosa, junk food, fast food dan peningkatan pola hidup sedenter (kurang gerak) yang semakin meningkat sebagai pengaruh dari urbanisasi dan modernisasi (Popkin, Adair \& Ng, 2013).

Pengukuran obesitas dapat dilakukan dengan berbagai cara. Pengukuran lemak tubuh yang paling akurat seperti dual-energi absorptiometri (DEXA), computed tomograpy (CT), dan magnetic resonance imaging (MRI). Namun, tidak praktis untuk digunakan sehari-hari (Purnell, 2018). Pengukuran perkiraan lemak tubuh melalui IMT (indeks masa tubuh) dan lingkar pinggang lebih mudah digunakan sehari-hari walaupun memiliki keterbatasan dibandingkan metode pencitraan. Perhitungan IMT dilakukan dengan membagi berat badan dalam kilogram dengan tinggi dalam meter kuadrat (Sinha \& Kling, 2009).

Kejadian obesitas di Indonesia menunjukkan angka yang cukup tinggi dan terus meningkat. Menurut data Riskesdas tahun 2018, prevalensi kejadian obesitas di Indonesia sebanyak $31,0 \%$ sedangkan tahun 2007 sebesar 18,8\%, 2013 sebesar 26,6\% (Riskesdas, 2018). Hal ini menunjukkan bahwa risiko komorbiditas akan meningkat berbanding lurus dengan peningkatan prevalensi obesitas (Kyrou, 2018).

Kejadian obesitas dipengaruhi oleh berbagai faktor. Faktor sosioekonomi yaitu kemampuan untuk memenuhi kebutuhan makan, akses pelayanan kesehatan serta ketersediaan fasilitas penunjang latihan merupakan suatu masalah pada penderita obesitas (Sinha \& Kling, 2009). Faktor nutrisi yaitu perilaku konsumsi makanan padat energi yang terlalu banyak (Agha \& Agha, 2017). Selain itu, pemilihan pemenuhan nutrisi yang buruk berupa konsumsi makanan cepat saji yang tidak terkontrol juga berperan besar dalam terjadinya obesitas (Shancez Villegaz, et al., 2013).

Tabel 1. Kriteria Obesitas pada Orang Dewasa menurut BMI.

\begin{tabular}{lcc}
\hline Classification & BMI $\left(\mathrm{kg} / \mathrm{m}^{2}\right)$ & Risk of Disease \\
\hline Underweight & $<18,5$ & - \\
Normal & $18,5-24,9$ & - \\
Overweight & $25-29,9$ & Increased \\
Obese class I & $30-34,9$ & high \\
Obese class II & $35-39,9$ & Very high \\
Obese class III & $\geq 40$ & Extremely high \\
\hline
\end{tabular}

Faktor fisiologis yang sering yang dapat meningkatkan kadar ghrelin menyebabkan obesitas adalah kurang tidur (sinyal untuk memulai makan) dan 
menurunkan kadar kadar leptin (sinyal untuk menghentikan makan) sehingga dapat menyebabkan peningkatan berat badan. Stress dapat meningkatkan prilaku konsumsi makanan cepat saji, cemilan, makanan tinggi kalori dan perilaku makan berlebih (Sinha \& Jastreboff, 2013).

Obesitas juga dapat disebabkan oleh faktor genetik yang dibawa oleh anak. Fenotip obesitas dibentuk dari interaksi antara faktor genetik dengan lingkungan. Faktor terpenting yang memainkan peran dalam obesitas adalah kurangnya aktivitas fisik yang dilakukan. Sehingga tidak terjadinya pengeluaran kalori yang seimbang dengan kalori yang masuk (Agha \& Agha, 2017).

Obesitas memiliki banyak efek negatif. Keadaan obesitas rentan menyebabkan penurunan sensitivitas insulin dan resistensi jaringan perifer terhadap insulin. Insulin merupakan hormon pankreas yang dihasilkan oleh sel $\beta$ Langerhan yang memiliki fungsi untuk mempertahankan keadaan normoglikemik (Praveen, et al,. 2012). Insulin menurunkan kadar glukosa darah dengan menginduksi penyerapan glukosa dalam jaringan yang sensitif insulin seperti otot dan jaringan lemak melalui Glucose Transporter-4 (GLUT-4) dan menghambat produksi glukosa dihati melalui penurunan pembentukan glukosa dengan prekusor bukan karbohidrat (glukoneogenesis) dan pemecahan glikogen menjadi glukosa (glikogenolisis) (Ye, 2013). Selain itu, insulin menstimulasi sintesis asam lemak dan glikogen, meningkatkan fungsi mitokondria, meningkatkan sirkulasi mikro dan menginduksi proliferasi sel (He, et al,. 2011).

Resistensi insulin merupakan kondisi di mana penyerapan glukosa yang diinduksi insulin terganggu. Hal ini disebabkan terjadinya kerusakan pensinyalan pada Insulin reseptor substrate (IRS) maupun Phosphatidylinositol 3-kinase (PI3K) sehingga translokasi suatu molekul transmembran GLUT-4 ke membran sel gagal. Pada keadaan ini, glukosa tidak dapat masuk ke dalam sel dan tidak dapat digunakan oleh sel tersebut sebagai sumber energi sehingga kadarnya meningkat dalam darah yang disebut dengan hiperglikemia (Akash, Rehman, Liaqat, 2018).

Resistensi insulin bisa disebabkan beberapa faktor seperti obesitas, peradangan, disfungsi mitokondria, hiperinsulinemia, lipotoksisitas/ hiperlipidemia, latar belakang genetik, stres oksidatif, penuaan dan kehamilan. 
Dari faktor tersebut, obesitas merupakan faktor tersering yang menyebabkan resistensi insulin yang diawali dengan berkurangnya jumlah reseptor insulin dan kegagalan reseptor untuk mengaktifkan tirosin kinase (Ye, 2013).

Obesitas visceral lebih berpotensi menyebabkan resistensi insulin. Jaringan adiposa merespon stimulasi nutrisi tambahan melalui hiperplasia dan hipertrofi adiposit (Elullu, Patimah, Khaza'ai, Rahmat, Abed, 2017). Dengan pembesaran adiposit progresif, suplai darah ke adiposit dapat berkurang, yang menyebabkan hipoksia (Cinti, et al., 2005). Hipoksia memicu nekrosis dan infiltrasi makrofag ke dalam jaringan adiposa, yang mengarah pada kelebihan produksi mediator proinflamasi yaitu TNF- $\alpha$ dan IL-6 serta penurunan produksi mediator antiinflamasi yaitu adiponektin (Karastergiou \& Mohamed-Ali, 2010). Hal ini menghasilkan peradangan lokal pada jaringan adiposa (Elullu, Patimah, Khaza'ai, Rahmat, Abed, 2017).

TNF- $\alpha$ mengganggu kerja insulin dengan menghambat pemberian sinyal untuk reseptor insulin dengan atau mengganggu aktivitas reseptor tirosin kinase melalui peningkatan fosforilasi serin/treonin IRS 1 dan 2. Apabila terjadi peningkatan fosforilasi serin/treonin pada reseptor maka terjadi penurunan fosforilasi tirosin. Penurunan fosforilasi tirosin akan menganggu kerja IRS 1 untuk bereaksi dengan phosphatidylinositol (PI)3- kinase (Ustunel, Friedrich, Maida, Wang, Herzig, Seibert, 2016). Penurunan aktivasi PI 3-kinase menyebabkan vesikel pada GLUT 4 tidak dapat berfusi dengan permukaan sel sehingga glukosa tidak dapat masuk ke dalam sel dan memberikan gambaran klinis berupa hiperglikemia yang dalam jangka waktu tertentu dapat berkembang menjadi diabetes mellitus (Akash, Rehman, Liaqat, 2018). 


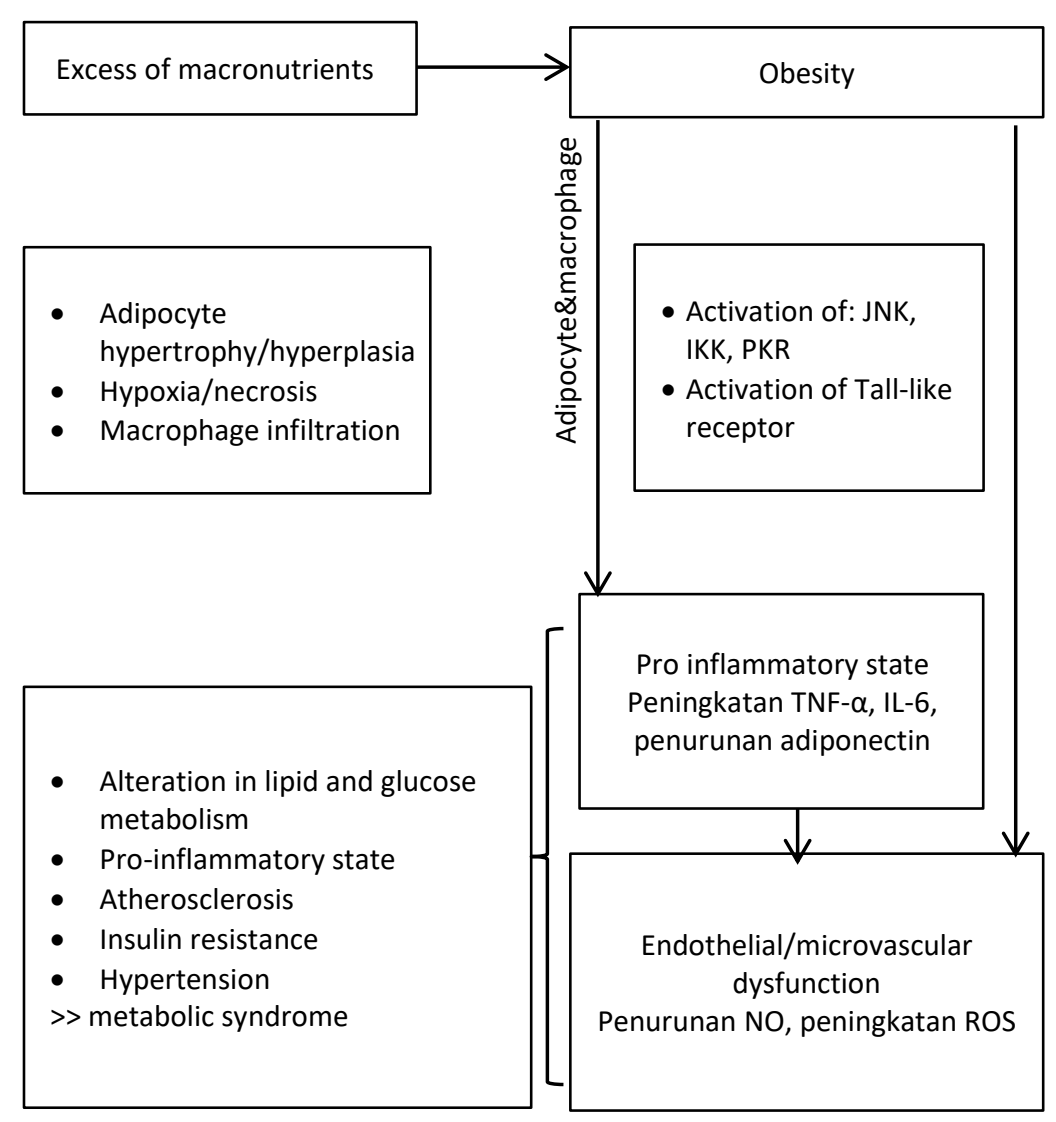

Gambar 1. Mekanisme yang menghubungkan obesitas abdominal dan sindrom metabolik melalui mediator inflamasi ;

(Elullu, Patimah, Khaza'ai, Rahmat, Abed, 2017)

Terapi berupa aktivitas fisik sangat penting untuk mengembalikan sensitivitas insulin sebagai upaya pencegahan terjadinya diabetes melitus akibat obesitas. Aktivitas fisik adalah semua gerakan yang menciptakan pengeluaran energi (Colberg, et al,. 2016). Pasien obesitas harus mengurangi intake kalori dan meningkatkan aktivitas fisik. Aktivitas fisik mampu meningkatkan pengeluaran kalori dan penurunan lemak sehingga mampu menurunkan berat badan. Selain itu, aktivitas fisik juga menurunkan resiko gangguan metabolik dan mortalitas dengan menciptakan keseimbangan energi (Hamasaki, 2016). Keseimbangan energi adalah proses di mana tubuh berusaha untuk membangun homeostasis. Untuk mencapai penurunan berat badan, American Diabetes Association (ADA) (Colberg, et al,. 2016), American Academy of Clinical Endocrinologists (AACE) (Handelman, et al., 2015), dan National Academy of Nutrition and Dietetics (Seagle, Strain, Makris, Reeves, 2009) 
merekomendasikan aktivitas fisik sebagai bagian integral dari program penurunan berat badan. AACE 2016 dan American College of Endocrinology dalam pedoman praktik klinis komprehensif untuk perawatan medis pasien dengan obesitas membuktikan bahwa rekomendasi aktivitas fisik intensitas sedang $\geq 150$ menit/minggu akan memberikan hasil yang lebih baik (Garvey, 2016).

Dibandingkan dengan kondisi istirahat, aktivitas fisik aerobik meningkatkan penyerapan glukosa di mana saja dari 1,5 hingga 10 kali lipat, tergantung pada intensitas aktivitas fisik (Turksoy, 2015). Intensitas aktivitas fisik dapat diketahui dengan menggunakan metode metabolic equivalent (MET). Aktivitas fisik dapat diklasifikasikan sebagai aktivitas fisik intensitas ringan ( $<3$ METs) intensitas sedang (3-6 METs) dan aktivitas intensitas intensitas berat $(>6$ METs) (Gonzales, Fuentes \& Markues, 2017). Aktivitas fisik intensitas ringan tidak mempengaruhi laju nafas seperti mencuci, setrika pakaian, makan, dan bekerja didepan komputer Aktivitas fisik intensitas sedang merupakan aktvitas yang dilakukan terus menerus paling tidak selama 60 menit dan dapat dilakukan sambil mengobrol tanpa terganggu seperti berjalan cepat, berenang dan tenis. Aktivitas yang dapat bertahan paling tidak selama 10 menit merupakan intensitas berat (Norton, Norton \& Sadgrove, 2010). Hasil penelitian menunjukkan bahwa untuk meningkatkan dan menjaga kesehatan, orang dewasa yang sehat berusia 18 hingga 65 tahun memerlukan aktivitas fisik baik intensitas sedang maupun berat. American College of Sports Medicine (ACSM) merekomendasikan aktivitas fisik intensitas sedang selama minimal 30 menit pada lima hari setiap minggu atau aktivitas fisik aerobik intensitas berat minimum 20 menit pada tiga hari setiap minggu atau kombinasi dari latihan intensitas sedang dan berat diperlukan untuk mencapai total pengeluaran energi $\geq 500-1000$ METs (Garber, et al., 2011). 
Tabel 2. Pengaruh aktivitas fisik terhadap sensitivitas insulin pada beberapa penelitian.

\begin{tabular}{|c|c|c|c|}
\hline $\begin{array}{c}\text { Sampel } \\
\text { penelitian }\end{array}$ & Metode & Perlakuan & Hasil \\
\hline $\begin{array}{lr}27 & \text { pasien } \\
\text { obesitas dan } \\
\text { pasien dengan } \\
\text { resistensi } \\
\text { insulin }\end{array}$ & Eksperimental & $\begin{array}{lr}\text { Intervensi } & \text { berupa } \\
\text { aktivitas } & \text { fisik } \\
\text { selama } 60 & \text { menit }\end{array}$ & $\begin{array}{lr}\begin{array}{l}\text { Satu kali } \\
\text { tersebut }\end{array} & \text { aktivitas } \\
\text { mempromosikan } & \\
\text { perubahan } & \text { yaitu } \\
\text { pengurangan } & \text { stres } \\
\text { seluler. Hal } & \text { ini } \\
\text { ditunjukkan } & \text { dengan } \\
\text { penurunan } & \text { HSP70. } \\
\text { Perubahan } & \text { tersebut } \\
\text { dapat berkontribusi pada } \\
\text { peningkatan SI yang } \\
\text { dipicu oleh latihan. }\end{array}$ \\
\hline $\begin{array}{lr}11 & \text { orang } \\
\text { dewasa } & \text { yang } \\
\text { kurang gerak } & \text { gan obesitas }\end{array}$ & $\begin{array}{l}\text { Randomised } \\
\text { controlled trial }\end{array}$ & $\begin{array}{lr}3 \text { perlakuan: } & (1) \\
\text { aktivitas } & \text { fisik } \\
\text { dengan target } & \mathrm{VO} 2 \\
50 \% \text { selama } & 70 \\
\text { menit } & \\
\text { (menghabiskan } 350 \\
\text { kkal), (2) aktivitas } \\
\text { fisik dengan target } \\
\text { VO2 65\% selama } 55 \\
\text { menit untuk } \\
\text { mengeluarkan } 350 \\
\text { kkal; (3) } \\
\text { melakukan } \\
\text { aktivitas. }\end{array}$ & \begin{tabular}{lr}
\multicolumn{2}{l}{ Aktivitas fisik selama 70} \\
menit dengan target \\
VO2 50\% meningkatkan \\
sensitivitas insulin \\
hingga & $35 \%$ \\
dibandingkan dengan \\
kelompok kontrol. \\
Sedangkan 55 menit \\
aktivitas fisik dengan \\
target $65 \%$ & VO2 \\
menghasilkan \\
peningkatan sensitivitas \\
insulin sebesar $20 \%$ \\
dibandingkan dengan \\
kondisi kontrol.
\end{tabular} \\
\hline $\begin{array}{l}61 \quad \text { laki-laki } \\
\text { obesitas }\end{array}$ & $\begin{array}{l}\text { Randomised, } \\
\text { controlled trial. }\end{array}$ & $\begin{array}{l}\text { Aktivitas fisik } \\
\text { intensitas sedang } \\
(300 \mathrm{kkal} / \mathrm{hari}) \text { atau } \\
\text { tinggi } \quad(600 \\
\mathrm{kkal} / \mathrm{hari}) \\
\text { minggu, selama } 11 \\
\text { dibandingkan } \\
\text { dengan kelompok } \\
\text { kontrol. }\end{array}$ & $\begin{array}{l}\text { Aktivitas fisik } \\
\text { meningkatkan } \\
\text { penyerapan glukosa } \\
\text { yang dipicu oleh insulin } \\
\text { pada otot rangka tetapi } \\
\text { tidak pada jaringan } \\
\text { adiposa. }\end{array}$ \\
\hline
\end{tabular}




\begin{tabular}{|c|c|c|c|}
\hline $\begin{array}{l}77 \text { perempuan } \\
\text { obesitas dan } \\
\text { kurang gerak. }\end{array}$ & $\begin{array}{l}\text { Prospective } \\
\text { controlled study. }\end{array}$ & $\begin{array}{l}\text { Latihan aerobic } 3 \\
\text { hari/minggu dengan } \\
\text { penurunan berat } \\
\text { badan dibandingkan } \\
\text { dengan penurunan } \\
\text { berat badan tanpa } \\
\text { latihan olahraga } \\
\text { selama } 6 \text { bulan }\end{array}$ & \begin{tabular}{lr} 
Terjadi & \multicolumn{2}{r}{ penurunan } \\
resistensi insulin pada \\
kedua \\
kelompok. \\
Pemanfaatan glukosa \\
meningkat $10 \%$ pada \\
kelompok latihan dan \\
penurunan berat badan \\
sedangkan $8 \%$ pada \\
kelompok penurunan \\
berat badan tanpa \\
olahraga.
\end{tabular} \\
\hline $\begin{array}{l}44 \text { perempuan } \\
\text { remaja gemuk }\end{array}$ & $\begin{array}{l}\text { Randomised } \\
\text { controlled trial. }\end{array}$ & $\begin{array}{l}\text { Latihan aerobic } 180 \\
\text { menit/minggu } \\
\text { dibandigkan dengan } \\
\text { kelompok kontrol } \\
\text { yang tidak diberikan } \\
\text { intervensi latihan } \\
\text { aerobic. }\end{array}$ & $\begin{array}{l}\text { Latihan aerobic secara } \\
\text { signifikan } \\
\text { meningkatkan } \\
\text { sensitivitas insulin } \\
\text { dibandingkan dengan } \\
\text { kelompok kontrol }\end{array}$ \\
\hline $\begin{array}{l}19 \quad \text { laki-laki } \\
\text { obesitas }\end{array}$ & $\begin{array}{l}\text { Randomised } \\
\text { control trial. }\end{array}$ & $\begin{array}{l}\text { Intervensi latihan } 2 \\
\text { minggu, } 4 \text { sesi per } \\
\text { minggu } \\
\text { intensitas tinggi }(10 \\
\times 60 \text { detik pada } 90 \% \\
\text { HRmax, (2) } 40-50 \\
\text { menit olahraga } \\
\text { terus-menerus } \\
\text { dengan intensitas } \\
\text { intensitas sedang } \\
\text { (Fatmax) }\end{array}$ & $\begin{array}{l}\text { Dalam jangka pendek ( } 2 \\
\text { minggu) latihan latihan } \\
\text { dengan intensitas sedang } \\
\text { terus menerus (Fatmax) } \\
\text { lebih efektif daripada } \\
\text { intensitas tinggi dalam } \\
\text { meningkatkan kontrol } \\
\text { glikemik. }\end{array}$ \\
\hline
\end{tabular}

Sumber: (Matos, et al., 2014), (Newsom, Everret, Hinko, Howowitz, 2013), (Reichkendle, et al., 2013), (Ryan, et al., 2014), (Lee, at al., 2013), (Lanzi, et al., 2015)

Aktivitas fisik intensitas berat lebih cenderung berkontribusi pada upaya penurunan berat badan dan pemeliharaan berat badan dalam jangka panjang (Cox, 2017).
Penelitian menunjukkan bahwa aktivitas fisik yang rutin menjadi komponen penting dari pemeliharaan berat badan setelah penurunan berat badan. Selain itu juga mampu peningkatan 
sensitivitas insulin, kebugaran kardiovaskuler, kontrol glikemik, tekanan darah dan depresi (Cox, 2017).

Penderita obesitas, lemak yang terakumulasi pada tubuh akan meningkatkan risiko untuk terjadinya peningkatan jumlah asam lemak bebas yang berujung pada terganggunya kaskade persinyalan insulin dan memberikan klinis hiperglikemia (Ustunel, et al., 2016). Pada penelitian Irving dkk. didapatkan bahwa aktivitas fisik intensitas tinggi dapat secara signifikan menurunkan berat badan, indeks massa tubuh, dan persen lemak tubuh (Irving, et al., 2008).

Individu yang kurang aktif secara fisik lebih mungkin untuk menambah berat badan dari waktu ke waktu daripada mereka yang melakukan aktivitas fisik rutin (Swift, Johannsen, Lavie, Earnest \& Cruch, 2014). Penelitian terbaru berdasarkan National Weight Control Registry (NWCR) menunjukkan bahwa aktivitas fisik rendah sampai berat mampu mempertahankan penurunan berat badan selama 3 tahun dengan pengeluaran energi rata-rata 383 kalori 7 hari / minggu. Penurunan berat badan akan diikuti dengan menurunnya lemak dalam tubuh dan penurunan pengeluaran sitokin proinflamasi. Sehingga mampu mencegah resistensi insulin dan mengembalikan sensitivitas insulin (Ogden, et al., 2014).

\section{PEMBAHASAN}

Obesitas merupakan suatu keadaan akumulasi lemak abnormal atau berlebihan pada jaringan adiposa tubuh yang disebabkan karena intake kalori yang berlebihan (pemasukan kalori) dibandingkan dengan pengeluaran kalori sehingga menyebabkan gangguan kesehatan. Keadaan obesitas berisiko menyebabkan penurunan sensitivitas insulin dan memicu berkembangnya resistensi insulin. Hal ini menyebabkan peningkatan kadar glukosa darah yang disebut hiperglikemia. Hiperglikemia dalam jangka panjang dapat berkembang menjadi diabetes mellitus.

Aktivitas fisik merupakan suatu modulator yang dapat memodulasi peningkatan sensitivitas insulin. Terapi ini bersifat mudah, murah dan efektif yang dapat mengatasi obesitas adalah dengan melakukan aktivitas fisik baik intensitas ringan, sedang maupun berat. American College of Sports Medicine (ACSM) merekomendasikan aktivitas fisik intensitas sedang selama minimal 30 menit pada 5 hari setiap minggu atau aktivitas fisik intensitas berat minimum 20 menit pada 3 hari setiap minggu atau kombinasi dari latihan intensitas sedang dan berat diperlukan untuk mencapai total 
pengeluaran energi $\geq 500-1000$ METs.

Konsisten dan rutin melakukan aktivitas fisik terbukti efektif untuk menurunkan berat badan dan pemeliharaan berat badan dalam jangka panjang. Hal ini berdampak pada pengembalian sensitivitas insulin dan mengatasi resistensi insulin pada obesitas.

\section{KESIMPULAN}

Obesitas merupakan masalah kesehatan yang terus meningkat setiap tahun di Indonesia. Peningkatan prevalensi obesitas akan meningkatkan risiko penyakit kronis terutama diabetes melitus karena penurunan sensitivitas insulin dan berkembangnya resistensi insulin. Aktivitas fisik intensitas ringan, sedang sampai berat merupakan salah satu upaya untuk mengatasi obesitas. Secara konsisten dan rutin melakukan aktivitas fisik intensitas sedang 5 kali dalam seminggu atau intensitas berat 3 kali dalam seminggu atau kombinasi keduanya berkontribusi dalam upaya penurunan berat badan dan pemeliharaan berat badan dalam jangka panjang sehingga mampu meningkatkan sensitivitas insulin dengan target pengeluaran energi $\geq 500-1000$ METs.

\section{SARAN}

Saran dari penulis untuk penelitian selanjutnya adalah melakukan penelitian lebih mendalam seperti penelitian langsung terhadap hewan coba ataupun terhadap manusia atau penelitian berupa laporan kasus agar hasil penelitian merupakan hasil yang didapatkan secara langsung atau melalui sumber primer.

\section{DAFTAR PUSTAKA}

Agha, M., \& Agha, R. (2017). The rising prevalence of obesity: part A: impct on public health. International Journal of Surgery, 2(7), 1-6.

Akash, MSH., Rehman, K., Liaqat, A. (2018) Tumor necrosis factoralpha: role in development of insulin resistance and pathogenesis of type 2 diabetes mellitus. J Cell Biochem, 119(1):105-10. doi: 10.1002/jcb.26174

Badan Penelitian dan Pengembangan Kesehatan. (2018). Riset Kesehatan Dasar (RISKESDAS). 1-384.

Bazzano, L, A., Hu, T., Bertisch, S, M., Yao, L., Harville, E, W.,...Redline, S. (2016). Childhood obesity patterns and relation to middle-age sleep apnoea risk: the Bogalusa Heart Study. Pediatric Obes, 11(6), 535-42.

Bhadoria, A., Sahoo, K., Sahoo, B., Choudhury, A., Sufi, N.,.....Kumar R. (2015). Childhood obesity: causes and consequences. J Fam Med Prim Care, 4(2), 187.

Borgeraas H, Barstad, L, H., Lund, S, R., Fredheim, J, M., Hertel, J, K., Hjelmesaeth, J. (2018) Association of time of obesity onset with comorbidities in treatment-seeking men and women with severe obesity. Obesity Science \&Practice, 4(5), 427-36. 
Cinti, S., Mitchell, G., Barbatelli, G., Murano, I., Ceresi, E., Faloia, E., ... Obin, MS. (2005) Adipocyte death defines macrophage localization and function in adipose tissue of obese mice and humans. J Lipid Res, 46(11):2347-2345. doi: 10.1194/jlr.M500294-JLR200

Colberg, SR., Sigal, RJ., Yardley, JE., Riddel, MC., Dunstan, DW., Dempsey, PC., ... Tate, DF. (2016) Physical activity/exercise and diabetes: a position statement of the American Diabetes Association. Diabetes Care, 39(11):2065-79. doi: $10.2337 / \mathrm{dc} 16-1728$

Cox, C, E. (2017). Role of physical activity for weight loss and weight maintenance. Diabetes Spectrum, 30(3), 150-60.

DiPietro, L., \& Stachenfeld NS. (2017). Exercise Treatment of Obesity. Endotext [Internet].

Ellulu, MS., Patimah, I., Khaza'ai, H., Rahmat, A., \& Abed, Y. (2017). "Obesity and Inflammation: The Linking Mechanism and the Complications. Arch Med Sci, 13(5), 851-863. doi: 10.5114/aoms.2016.58928

Garber, C, E., Blissmer, B., Deschenes, M, R., Franklin, B, A., Lamonte, M, J.,... Swain, D, P. (2011). American college of sports medicine position stand. Quantity and quality of exercise for developing and maintaining cardiorespiratory, musculoskeletal, and neuromotor fitness in apparently healthy adults: gidance for prescribing exercise. Med Sci Sports Exerc, 43(7), 1334-59.
Garvey, WT., Mechanick, JI., Brett, EM. Garber, AJ., \& Hurley, DL., Jastreboff AM., ... Plodkowski, R. (2016) AACE/ACE comprehensive clinical practice guidelines for medical care of patients with obesity. Endocr Pract, 22(Suppl. 3):1-203. doi: 10.4158/EP161365.GL

Gonzales, K., Fuentes, J., Markues, J, L. (2017). Physical inactivity, sedentary behavior and chronic disease. Korean Journal of Family Medicine, 38(3), 111-15.

Goossens, G, H. (2017) The metabolic phenotype in obesity: fat mass, body fat, and adipose tissue function. The European Jurnal of Obesity, 10(3), 208-15.

Hamasaki, H. (2016) Daily physical activity and type 2 diabetes: A review. World J Diabetes, 7(12):243-51. doi: 10.4239/wjd.v7.i12.243

Handelman, Y., Bloomgarden, Z., Grunberger, G., Umpierrez, G., Zimmerman, RS., Bailey, TS., ... Zangeneh, F. (2015) American Association of Clinical Endocrinologists and American College of Endocrinology clinical practice guidelines for developing a diabetes mellitus comprehensive care plan-2015. Endocr Pract, 21(Suppl. 1):1-87. doi: 10.4158/EP15672.GL

He, Q., Gao, Z., Yin, J., Zhang, J., Yun, Z.,......Ye, J. (2011). Reglukosation of HIF- $1 \alpha$ activity in adipose tissue by obesity-associated factors: adipogenesis, insulin, and hypoxia. 
Am J Physiol Endocrinol Metab, 300(5), E877-E85.

Hruby A, Hu F,B. (2015). The epidemiology of obesity : a big picture. HHS Public Access, 33(7), 1-29.

Irving, B, A., Davis, C, K., Brock, D, W., Weltman, J,Y., Swift, D.,.....Weltman. (2008). Effect of exercise training intensity on abdominal visceral fat and body composition. Med Sci Sports Exerc,40(11), 1863-72.

Karastergiou K \& Mohamed-Ali V. (2010). The autocrine and paracrine roles of adipokines. Mol Cell Endocrinol, 318(1-2), 69-78.

Kyrou, I., Randeva, H, S., \& Tsigos, C. (2018). Clinical Problems Caused by Obesity. Endotext [Internet]. South Dartmouth (MA).

Lanzie, S., Codesava, F., Cornacchia, M., Maestrini, S., Capodaglio, P., Brunani, A.......Malatesta, D. (2015). Short-term HIIT and fat max training increase aerobic and metabolic fitness in men with class II and III obesity,23(10), 1987-94.

Lee, S., Delsin, AR., White, A., Kim, YM., Libman, I......Arslanian, S.(2013). Aerobic exercise but not resistance exercise reduces intrahepatic lipid content and visceral fat and improves insulin sensitivity in obese adolescent girls: a randomized controlled trial. Am J Physiol Endocrinol Metabl, 305(10), 1222-29.

Matos, MA., Ottone, VO., Sampaio PFM., Costa, KB., Fonseca, CA., Neves MPC.........Amorim, FT. (2014). Exercise reduces cellular stress related to skeletal muscle insulin resistane. Cell Stress and Caperones, 19, 263-70.

Newsom, SA., Everret, AC., Hinko, A., Horowitz, JF. (2013). A single session of low intensity exercise is sufficient to enhance insulin sensitivity into the next day obese adults. Diabetes Care, 36, 2516-22.

Norton, K., Norton, L., Sadgrove, D. (2010). Position statement on physical activity and exercise intensity terminology. J Sci Med Sport, 13(5), 496-502.

Ogden, L, G., Phelan, S., Thomas, J, G., Hill, J, O., Wing, R, R.,.... Wyatt, H, R. (2014). Dietary habits and weight maintenance success in high vs low exercisers in the National Weight Control Registry. J Phys Act Health, 11(8), 1540-48.

Popkin B,M., Adair L,S., Ng S,W. (2013). Now and then: the global nutrition transition: the pandemic of obesity in developing countries. Nutr Rev, 70(1), 3-21.

Praveen, E, P., Sahoo, J., Khurana, M, L.,Kulshretsha, B., Khadgawat, R.,....Ammini, A,C. (2012). Insulin sensitivity and $\beta$-cell function in normoglycemic offspring of individuals with type 2 diabetes mellitus: Impact of line of inheritance. Indian $\mathrm{J}$ Endocrinol Metab, 16(1), 105-111.

Reichkendler, MH., Auerbach, P., Rosenklide, M., Christensen, AN., Holm, S., Petersen MB........Stallknecht, B. (2013). Exercise training favors increased insulin-stimulated glucose uptake in skeletal muscle in contrast to 
adipose tissue: a randomized study using FGD PET imaging. Am J Physiol Endocrinol Metab, 305(4), 496-496.

Ryan, AS., Shealinna., Blumenthal, JB., Monica, C., Serra., Prior, SJ., Goldberg, AP. (2014). Aerobic exercise and weight loss reduce vascular markers of inflammation and improve insulin sensitivity in obese women. J Am Geriatr Soc, 62(4), 607-14.

Sanchez-Villegas, A., Field, A, E., O'Reilly, E,J., Fava, M., Gortmaker, S.,...Ascherio, A. (2013). Perceived and actual obesity in childhood and adolescence and risk of adult depression. J Epidemiol Community Health, 67(1), 81-6.

Seagle, HM., Strain, GW., Makris, A., \& Reeves, RS. (2009) American Dietetic Association. Position of the American Dietetic Association: weight management. J Am Diet Assoc, 109(2):330-46. doi: 10.1016/j.jada.2008.11.041

Segula, D. (2014). Complications of obesity in adults: a short review of the literature. Malawi Med J, 26(1), 20-4.

Sinha, A., \& Kling, S. (2009). A review of adolescent obesity: Prevalence, etiology, and treatment. Obes Surg, 19(1), 113-20.

Sinha, R., \& Jastreboff, A, M. (2013). Stress as a common risk factor for obesity and addiction. Biol Psychiatry, 73(9), 827-35.

Swift, D,L., Johannsen, N, M., Lavie, C, J., Earnest, C, P \& Church, T, S. (2014). The role of exercise and physical activity in weight loss and maintenance. Prog Cardiovasc Dis, 56(4), 441-7.

Turksoy, K., Paulino, TML., Zaharieva, DP., Yavelberg, L., Jamnik, V., Riddell, C., ... Cinar A. (2015) Classification of physical activity: information to artificial pancreas control systems in real time. $\mathrm{J}$ Diabetes Sci Technol, 9(6):12001207.

Ustunel, BE., Friedrich, K., Maida, A., Wang, X., Herzig, AK., \& Seibert, O. (2016) Control of diabetic hyperglicaemia and insulin resistance through TSC22D4. Nat. Commun, 7(13267):1-11. doi: $10.1038 /$ ncomms 13267

WHO. (2018). Obesity and Overweight. Geneva: WHO.

Ye, J. (2013). Mechanisms of insulin resistance in obesity. Front Med, 7(1), 1-17. 